\title{
A análise da
}

(in)constitucionalidade no

processo administrativo fiscal*

The analysis of the

unconstitutionality in the

administrative tax process

\author{
Melina Rocha Lukic**
}

\section{RESUMO}

Apesar da Constituição Federal de 1988 garantir o acesso e a ampla defesa em processo administrativo fiscal para a discussão de créditos tributários, os órgãos designados para tal fim têm se eximido da apreciação da constitucionalidade de leis e atos normativos infralegais sob a alegação de que tal atribuição é exclusiva do Poder Judiciário. O objetivo do presente artigo é, portanto, fixar premissas para a análise da questão verificando: $a$ ) se a administração pública pode exercer atividade jurisdicional, $b$ ) se os julgadores administrativos podem efetuar o controle difuso de constitucionalidade e $c$ ) se podem aplicar e interpretar o ordenamento jurídico de forma parcial, sem considerar os ditames da Constituição Federal.

\section{PALAVRAS-CHAVE}

Processo administrativo fiscal - constitucionalidade

* Artigo recebido em outubro de 2011 e aprovado em novembro de 2011.

** Professora da Escola de Direito FGV-Rio, doutoranda na Université Paris III (Sorbonne Nouvelle). 


\section{ABSTRACT}

Although the Federal Constitution of 1988 ensure the access in an administrative fiscal process to discuss the tax credit, the bodies designated for this purpose have been exempted from the examination of the constitutionality of laws and other normative acts. The aim of this paper is to analyze: a) if the administration can exercise judicial activity, b) if the administrative judges can make the diffuse control of constitutionality and c) if they can apply and interpret the laws partially, regardless of the dictates of the Constitution.

\section{KEY-WORDS}

Fiscal administrative procedure - constitutionality

A Constituição Federal de 1988 garantiu aos sujeitos passivos de um crédito tributário a possibilidade de questionar a legitimidade deste não só perante o Poder Judiciário, mas também através de um processo administrativo a ser apreciado por órgãos julgadores da administração pública especialmente estruturados para esse fim.

Apesar de o art. 5으 LV da Constituição Federal de 1998 assegurar a ampla defesa aos litigantes, tanto em processo judicial como em administrativo, e a alínea a, do inciso XXXIV do mesmo artigo, assegurar o direito de petição aos poderes públicos em defesa de direitos ou contra ilegalidade ou abuso de poder, os órgãos julgadores administrativos têm se eximido da apreciação da constitucionalidade de leis e atos normativos infralegais, sob a alegação de que somente o Poder Judiciário teria competência para tal fim.

Para o debate da questão, necessário o enfrentamento de uma série de pressupostos que não foram, até então, suficientemente abordados pela doutrina que se manifesta sobre o assunto. Esses pressupostos, que serão desenvolvidos no presente artigo, dizem respeito à: a) questão da possibilidade de exercício da atividade jurisdicional pelos órgãos julgadores administrativos, b) diferença entre controle difuso e concentrado da constitucionalidade das leis e possibilidade do controle difuso pelos julgadores administrativos, c) função e poderes (e seus limites) do agente administrativo em contraposição à função e poderes do julgador administrativo e d) necessidade de interpretação sistemática e una do direito na função jurisdicional. 
Abordaremos, a seguir, todas essas questões para ao final concluirmos pela possibilidade ou não de julgadores administrativos aferirem a constitucionalidade de lei e atos normativos no exercício de suas funções. Assim, iniciaremos a abordagem pela verificação de como os órgãos julgadores administrativos, bem como a doutrina, vêm tratando o tema.

\section{Do tratamento da inconstitucionalidade no processo administrativo pelos órgãos julgadores fiscais e pela doutrina}

A posição atual dos principais órgãos julgadores administrativos é de prever em seus regimentos internos ou através de súmulas e decisões reiteradas a sua incompetência para apreciar as questões constitucionais a eles submetidas.

O principal órgão julgador fiscal - o Conselho Administrativo de Recursos Fiscais (Carf) - que aprecia questões envolvendo tributos federais prevê, no art. 62, do anexo II do seu Regimento Interno, aprovado pela Portaria MF no 256/2009, que "fica vedado aos membros das turmas de julgamento do Carf afastar a aplicação ou deixar de observar tratado, acordo internacional, lei ou decreto, sob fundamento de inconstitucionalidade".

O inciso primeiro do parágrafo único desse mesmo dispositivo traz a previsão de que "o disposto no caput não se aplica aos casos de tratado, acordo internacional, lei ou ato normativo que já tenha sido declarado inconstitucional por decisão plenária definitiva do Supremo Tribunal Federal".

$\mathrm{O}$ art. 62-A ressalva, no entanto, que, caso o mérito da matéria já tenha sido decidido definitivamente pelo Supremo Tribunal Federal (STF) na sistemática prevista pelo art. 543-B do Código de Processo Civil, deverão as decisões ser reproduzidas pelos conselheiros no julgamento dos recursos no âmbito do Carf.

Relativamente ao Carf, as súmulas ํㅡㄹ 2/06 dos extintos 1ㅇ e 2o Conselhos de Contribuintes dispunham que "o Conselho de Contribuintes não é competente para se pronunciar sobre a inconstitucionalidade de lei tributária".

Além disto, a maioria dos órgãos julgadores administrativos dos estados trata a matéria da mesma forma. O Conselho de Contribuintes da Secretaria do Estado da Fazenda do Estado do Rio de Janeiro, apesar de não prever expressamente em seu regimento interno norma impeditiva de apreciação de questões constitucionais, tem reiteradas decisões no sentido de que "a apreciação de constitucionalidade de leis foge ao exame deste Órgão Julgador 
Administrativo;"1 "não cabe a esta instância administrativa se pronunciar, quanto à constitucionalidade da Legislação Estadual"2 e "não compete à via administrativa aferir aspectos de constitucionalidade da legislação tributária em pleno vigor". ${ }^{3}$

Interessante é a análise dos fundamentos (ou da falta deles) levantados em alguns dos julgados do Conselho de Contribuintes do Estado do Rio de Janeiro, como é o caso do voto do relator Eduardo Caetano Garcia, exarado nos autos do processo no E04/701.821/1996:

No que tange à primeira, da obrigatoriedade da autoridade administrativa manifestar-se sobre constitucionalidade de lei fiscal, salta aos olhos do menos avisado cidadão com mediano conhecimento jurídico tributário que a qualquer instância de julgamento tributário da Secretaria de Estado de Fazenda falece total competência para dizer da constitucionalidade ou não de uma norma legal afeta ao seu mister. De conseguinte, lamentando tamanha bobagem arguida em forma de preliminar resta-me, tão somente, dizer, não a acolho.

Decisões mais recentes do Conselho de Contribuintes do Rio de Janeiro, entretanto, fazem referência aos arts. 5으, inciso XXXV, 97, 102 e 125, § 2o, da Constituição Federal, como fundamentação ao argumento de que o controle de constitucionalidade de leis e atos normativos é de competência privativa do Poder Judiciário. ${ }^{4}$

Já quanto ao Tribunal de Impostos e Taxas (TIT) do estado de São Paulo, a Lei no $13.457 / 2009$ e o Decreto no 54.486/2009 dispõem nos arts. 28 e 93, respectivamente, que

no julgamento é vedado afastar a aplicação de lei sob alegação de inconstitucionalidade, ressalvadas as hipóteses em que a inconstitucionalidade tenha sido proclamada: I - em ação direta de inconstitucionalidade; II - por decisão definitiva do Supremo Tribunal Federal, em via incidental, desde que o Senado Federal tenha suspendido a execução do ato normativo.

\footnotetext{
${ }^{1}$ Acórdão no 5.545, sessão de 17 de setembro de 2007.

${ }^{2}$ Acórdão no 6.596, publicado em 2/10/2008.

${ }^{3}$ Acórdão no 8.263, publicado em 19/5/2010.

${ }^{4}$ Acórdão no 8.222, publicado em 28/5/2010.
} 
O inciso primeiro do art. 20 do Regimento Interno do TIT fala ainda que "cabe reforma da decisão contrária à Fazenda Pública do Estado, da qual não caiba a interposição de recurso, quando a decisão reformanda afastar a aplicação da lei por inconstitucionalidade, observadas as exceções previstas em lei".

A jurisprudência desse órgão administrativo tem, assim, se manifestado no sentido de que o "controle de constitucionalidade é atividade do poder judiciário", 5 a "constitucionalidade de lei afeta a apreciação da Suprema Corte, guardiã da Magna Carta", ${ }^{6}$ há "vedação expressa da nova legislação paulista (artigo 28 da Lei no 13.457/2009) em afastar lei sob a alegação desta ser contrária à Constituição". ${ }^{7}$

O TIT ainda se pronunciou sobre a competência para declaração de constitucionalidade na concessão de incentivos fiscais e em casos envolvendo guerra fiscal entre os estados, conforme os seguintes trechos:

A norma que concede incentivo fiscal, se concedida ao arrepio do ordenamento jurídico, deve ser atacada junto ao Poder Judiciário, órgão competente para declaração de inconstitucionalidade de normas, sob pena de usurpação de competência do Supremo Tribunal Federal (art. 102 da CF/88) e exercício arbitrário das próprias razões. ${ }^{8}$

Adotar como fundamentação (premissa de lançar) do AIIM a invalidade de normas de outras UF's representa exercer o controle de constitucionalidade pela via difusa, só cabível ao Poder Judiciário. ${ }^{9}$

$\mathrm{Na}$ esteira dos entendimentos dos órgãos julgadores administrativos, uma parte significante da doutrina igualmente não admite a apreciação de matéria constitucional por esses órgãos. Marcos Vinícius Neder e Maria Teresa Martinez Lopes consideram que "as decisões administrativas são espécies de ato administrativo e, como tal, sujeitam-se ao controle do Judiciário" e, por isso, afirmam que:

Se, por acaso, a fundamentação do ato administrativo baseou-se em norma inconstitucional, o Poder que tem atribuição para examinar a

\footnotetext{
${ }^{5}$ Processo no 456669/2006, publicado em 9/1/2010.

${ }^{6}$ Processo no 397617/2001, publicado em 9/1/2010.

${ }^{7}$ Processo no 531085/2006, publicado em 20/11/2009.

${ }^{8}$ Processo no 928005/2006, publicado em 19/6/2010.

${ }^{9}$ Processo no 7421/2009, publicado em 7/11/2009.
} 
existência de tal vício é o Poder Judiciário. Afinal, presumem-se constitucionais os atos emanados do Legislativo, e, portanto, a eles vinculamse as autoridades administrativas. ${ }^{10}$

Hugo de Brito Machado chama a atenção ao fato de que "a verdadeira questão não reside em saber se uma autoridade administrativa pode recusar aplicação a uma lei inconstitucional, mas em saber se ela tem competência para dizer se a lei é inconstitucional" (Machado, 2002: 153-154). ${ }^{11}$ Segundo esse jurista, em primeiro lugar, "nossa Constituição não alberga norma que atribua às autoridades da Administração competência para decidir sobre a inconstitucionalidade de leis. Assim, já é possível afirmar-se que no desempenho de atividades substancialmente administrativas o exame da inconstitucionalidade é inadmissível". ${ }^{12}$

Mesmo quando a administração desempenha atividade jurisdicional, através dos órgãos do Contencioso Administrativo Fiscal, não se poderia admitir o exame de arguições de inconstitucionalidade, porque tal fato ensejaria "a prevalência de decisões divergentes sobre um mesmo dispositivo de uma lei, sem qualquer possibilidade de uniformização. Acolhida a arguição de inconstitucionalidade, a Fazenda não pode ir ao Judiciário contra a decisão de um órgão que integra a própria Administração". ${ }^{13}$ Assim, Machado afirma que a consequência seria o fato de a decisão administrativa tornar-se definitiva, sem a devida apreciação pelo STF, "que é, em nosso ordenamento jurídico, o responsável maior pelo deslinde de todas as questões de constitucionalidade, vale dizer, 'o guardião da Constituição'". ${ }^{14}$

O citado autor assim conclui sobre a questão:

É sabido que o princípio da supremacia constitucional tem por fim garantir a unidade do sistema jurídico. É sabido também que ao STF cabe a tarefa de garantir essa unidade, mediante o controle da constitucionalidade das leis. Não é razoável, portanto, admitir-se que uma autoridade administrativa possa decidir a respeito dessa constitucionalidade,

\footnotetext{
${ }^{10}$ NEDER, Marcos Vinícius; LOPES, Maria Teresa Martinez. Processo administrativo fiscal federal comentado. São Paulo: Dialética, 2004. p. 47-48.

${ }^{11}$ MACHADO, Hugo de Brito. Algumas questões do processo administrativo tributário. In: MARTINS, Ives Gandra da Silva. Processo administrativo tributário. São Paulo: RT, 2002. p. 153-154.

12 Ibid.

13 Ibid.

${ }^{14}$ Ibid.
} 
posto que o sistema jurídico não oferece instrumentos para que essa decisão seja submetida à Corte Maior.

A conclusão mais consentânea com o sistema jurídico brasileiro vigente, portanto, há de ser no sentido de que a autoridade administrativa não pode deixar de aplicar uma lei por considerá-la inconstitucional, ou, mais exatamente, a de que a autoridade administrativa não tem competência para decidir se uma lei é ou não inconstitucional.

Tal conclusão, que aparentemente contraria o princípio da supremacia constitucional, na verdade o realiza melhor do que a solução oposta, na medida em que preserva a unidade do sistema jurídico, que é objetivo maior daquele princípio. ${ }^{15}$

Conclui-se, portanto, que o tratamento atual da matéria tem sido, no entendimento dos órgãos julgadores administrativos e de parte da doutrina, pela impossibilidade de apreciação de matéria constitucional em processo administrativo fiscal. A principal razão levantada é a de que esta competência seria exclusiva do Poder Judiciário, de acordo com o inciso XXXV, do art. 5o da Constituição Federal.

Essa apreciação é permitida, no entanto, se a matéria já tenha sido julgada definitivamente pelo STF em controle concentrado de constitucionalidade ou esteja pacificada por meio de súmula vinculante. Assim, a prática atual das instâncias julgadoras administrativas é a de não conhecer questões que levantem matéria constitucional.

\section{Da função jurisdicional dos julgadores administrativos}

Premissa primeira para a análise da questão está em se saber se o órgão administrativo, ao julgar controvérsias envolvendo matéria tributária, exerce função jurisdicional ou apenas um controle dos atos da administração pública.

Conforme bem observado por Cândido Rangel Dinamarco e J.E. Carreira Alvim, a palavra jurisdição é formada pelos vocábulos latinos juris (direito) e dictio (substantivo derivado do verbo dizer). ${ }^{16}$ Apesar de a concepção moder-

\footnotetext{
15 Ibid.

${ }^{16}$ DINAMARCO, Cândido Rangel. Instituições de direito processual civil. São Paulo: Malheiros, 2005. p. 337; ALVIM, J.E. Carreira. Teoria geral do processo. Rio de Janeiro: Forense, 2007. p. 54.
} 
na de jurisdição incluir muito mais do que o simples fato de "dizer o direito", a origem etimológica da palavra já nos dá pistas de que seu conteúdo semântico envolve o fato de aplicar a lei diante de um determinado caso concreto.

Dinamarco define jurisdição como a "função do Estado, destinada à solução imperativa de conflitos e exercida mediante a atuação da vontade do direito em casos concretos" ${ }^{17}$ Segundo esse autor, o escopo da jurisdição, e o que a difere das demais funções do Estado, é o fato de dar efetividade ao direito material em casos concretos. ${ }^{18}$ J.E. Carreira Alvim acrescenta que "a jurisdição é uma função do Estado, pela qual este atua o direito objetivo na composição dos conflitos de interesse, como fim de resguardar a paz social e o império da norma de direito" ${ }^{19} \mathrm{O}$ caráter substitutivo da jurisdição é colocado em evidência no conceito de Cintra, Grinover e Dinamarco, que entendem que essa "é uma das funções do Estado, mediante a qual este se substitui aos titulares dos interesses em conflito que os envolve, com justiça". ${ }^{20}$

Para fins do presente estudo, importante diferenciar as funções estatais de jurisdição, legislação e administração. A jurisdição, assim como a função legislativa, é uma atividade jurídica do Estado. ${ }^{21}$ Enquanto a jurisdição dá efetividade à lei, tendo por função "pacificar situações conflituais apresentadas ao Estado-juiz", ${ }^{22}$ a função legislativa é ligada à produção jurídica, à criação de normas gerais e abstratas que regularão a conduta dos indivíduos. Já a administração, por outro lado, não tem objetivos jurídicos, mas o de propiciar o bem comum, nos limites da lei. ${ }^{23}$

Ao diferenciar as funções estatais de jurisdição e administração, J.E. Carreira Alvim sublinha o fato de que a natureza ou a qualidade do órgão que pratica determinado ato não é suficiente para caracterizá-lo como administrativo ou jurisdicional. Ou seja, o fato de o ato ser emanado pelo Poder Judiciário não o faz automaticamente um ato jurisdicional, bem como, logicamente, nem todos os atos praticados pela administração pública serão atos administrativos. Segundo Alvim, "se é certo que habitualmente as duas funções estão confiadas a órgãos distintos, isto nem sempre acontece, pois há órgãos

\footnotetext{
${ }^{17}$ Dinamarco, Instituições de direito processual civil, op. cit., p. 330.

18 Ibid.

${ }^{19}$ Alvim, Teoria geral do processo, op. cit., p. 55.

${ }^{20}$ CINTRA, Antonio Carlos de Araújo; GRINOVER, Ada Pellegrini; DINAMARCO, Cândido Rangel. Teoria geral do processo. São Paulo: Malheiros Editora, 2008. p. 148.

${ }^{21}$ Dinamarco, Instituições de direito processual civil, op. cit., p. 330.

${ }^{22}$ Cintra, Grinover e Dinamarco, Teoria geral do processo, op. cit., p. 152.

${ }^{23}$ Dinamarco, Instituições de direito processual civil, op. cit., p. 330.
} 
jurisdicionais investidos de funções administrativas e órgãos administrativos investidos de funções jurisdicionais".$^{24} \mathrm{O}$ principal critério apontado por esse autor para diferenciar ambas as funções seria o fato de a jurisdição ser uma "atividade de substituição" na tarefa de composição de conflitos de interesses. Na atividade da administração, ao contrário, o Estado age em seu próprio nome, nos limites da lei..$^{25}$

Conclusão importante é, assim, a de que o exercício da jurisdição não é exclusivo dos órgãos do Poder Judiciário, podendo tal função ser exercida, de forma atípica, igualmente pelo Poder Executivo e pelo Poder Legislativo. Os poderes Executivo, Legislativo e Judiciário têm suas competências amplamente definidas pela Constituição Federal de 1988. Ocorre que no exercício de suas atividades os diferentes órgãos desses poderes não exercem exclusivamente funções que lhes são próprias. Assim, esses órgãos podem vir a exercer não somente suas funções típicas, mas igualmente funções a eles atípicas, atinentes aos outros poderes. A administração pública, portanto, apesar de ter a função executiva como intrínseca à sua existência, também pode (e deve) exercer funções atinentes a outros órgãos, como a função legislativa e jurisdicional.

Neste sentido, costuma-se dividir a administração em administração ativa, em referência àquelas atividades tipicamente atribuídas pela Carta Magna, e a administração judicante, quando exerce função típica do Poder Judiciário - a jurisdição -, como ocorre no caso dos órgãos julgadores administrativos.

Assim, se verificarmos o papel da administração no processo de positivação do direito tributário, pode-se concluir que ela pode exercer uma função legislativa, ao expedir normas regulamentadoras de leis, por exemplo; uma função tipicamente executiva, ao efetuar o lançamento de ofício de tributos, e, finalmente, uma função jurisdicional, através de órgãos específicos, que apreciam e julgam as matérias atinentes à questão tributária.

Não se pode deixar de mencionar, todavia, controvérsia doutrinária acerca da natureza do processo administrativo fiscal: se exerce função jurisdicional ou apenas efetua o controle dos atos da administração pública. Prestigiados autores, como Paulo de Barros Carvalho, consideram o processo administrativo fiscal (ou procedimento administrativo tributário, como prefere chamar) um "plexo de formalidades, armadas para o escopo de exercitar o controle de

\footnotetext{
${ }^{24}$ Alvim, Teoria geral do processo, op. cit., p. 58.

${ }^{25}$ Ibid., p. 62.
} 
legalidade de certos e determinados atos administrativos, como o lançamento, a imposição de penalidades e a notificação". ${ }^{26}$ Para esse autor, o procedimento fiscal, ao contrário dos processos na esfera judicial, "não persegue, como finalidade primeira e imediata, a concretização de critérios de Justiça" ${ }^{27}$ Essa finalidade caberia somente ao Poder Judiciário que, ao exercer a atividade jurisdicional, aplica o direito positivo na composição de litígios, realizando, portanto, "os mais elevados padrões de Justiça". ${ }^{28}$

No mesmo sentido, Hugo de Brito Machado Segundo afirma que:

Enquanto o processo judicial é instrumento para o exercício da tutela jurisdicional, através da qual o Poder Judiciário, inerte e imparcial, soluciona de modo definitivo conflitos verificados entre terceiros, inclusive relativamente a atos praticados pelo Poder Executivo e pelo Poder Legislativo, o processo administrativo é um instrumento para o exercício da autotutela, através do qual a Administração envolvida no conflito admite rever seus próprios atos, quando impugnados pelo administrado que por ele se sentiu prejudicado, ou mesmo de oficio. ${ }^{29}$

Entretanto, a partir dos conceitos de jurisdição acima apresentados, podemos verificar que a função exercida pelos julgadores administrativos também se caracterizaria como uma atividade jurisdicional, eis que efetivamente o Estado, em uma atividade substitutiva, aplica o direito a situações concretas de conflito, visando solucioná-las.

Neste sentido, Paulo Cesar Conrado reconhece que "a atividade desenvolvida pela Administração nos aludidos processos (administrativos) é, mesmo que atipicamente, manifestação jurisdicional - (i) é estatal (...) e (ii) tendente à composição de conflitos (... $)^{\prime \prime} .^{30}$

Os principais argumentos contra a possibilidade de atividade jurisdicional por parte dos órgãos administrativos dizem respeito à alegada falta de dois elementos essenciais dessa função: o caráter substitutivo e a coisa julgada.

\footnotetext{
${ }^{26}$ CARVALHO, Paulo de Barros. Direito tributário: linguagem e método. São Paulo: Noeses, 2009. p. 903.

${ }_{27}$ Ibid., p. 902.

${ }^{28}$ Ibid., p. 903.

${ }^{29}$ MACHADO SEGUNDO, Hugo de Brito. Impossibilidade de declaração de inconstitucionalidade de lei pela autoridade administrativa de julgamento. Revista Dialética de Direito Tributário, São Paulo, n. 98, p. 98, 2003.

${ }^{30}$ CONRADO, Paulo Cesar. Processo tributário. São Paulo: Quartier Latin, 2004. p. 108.
} 
A primeira característica essencial da jurisdição, conforme conceito de Cintra, Grinover e Dinamarco antes exposto, seria o seu caráter substitutivo. Ou seja, o Estado substitui as partes para a composição dos conflitos dessas. Disso decorre a necessidade de imparcialidade do julgador. Por conta desse elemento, muitos defendem que a ausência de atividade substitutiva nos órgãos de julgamento da administração pública, por estarem estes inseridos dentro da própria administração e ela ser exercida pelos próprios agentes administrativos, descaracterizaria a função jurisdicional. Inexistiria, nesse caso, a imparcialidade do julgador, eis que a própria parte estaria decidindo sobre conflito no qual tem interesse.

Nesse sentido, Marçal Justen Filho não considera a possibilidade de um "processo administrativo", tendo em vista que os órgãos julgadores não são independentes, integrando a própria administração pública. Segundo esse autor, "o sistema brasileiro alicerça-se na unidade da jurisdição, atribuída ao Poder Judiciário". E continua afirmando que "supor a existência de processo com cunho de jurisdicionalidade, fora do âmbito do poder Judiciário, é contrário à Constituição". ${ }^{31}$

Tais argumentos, a nosso ver, não procedem. Primeiro, porque os órgãos julgadores fiscais são compostos por agentes administrativos destacados especialmente para esse fim e que não integram, portanto, o quadro funcional da administração com atribuições puramente executivas. O Conselho Administrativo de Recursos Fiscais, por exemplo, possui função específica, realiza suas atividades com elevado grau de autonomia e sua composição é formada por representantes do Estado e da iniciativa privada. ${ }^{32}$ Há que se diferenciar, conforme faremos a seguir, as funções administrativas das funções jurisdicionais, mesmo que ambas sejam realizadas no seio da administração pública.

Outro argumento levantado para fundamentar que o processo administrativo fiscal não tem caráter jurisdicional diz respeito ao fato de este não fazer coisa julgada material. Os atos praticados pelos agentes públicos podem ser passíveis de revisão pelo Poder Judiciário, pois, segundo o inciso XXXV do art. 5o da CF/88, "a lei não poderá excluir da apreciação do Poder Judiciário lesão ou ameaça a direito". Dessa forma, tanto os atos administrativos stricto sensu quanto os atos jurisdicionais administrativos poderão ter a legalidade

\footnotetext{
${ }^{31}$ JUSTEN FILHO, Marçal. Curso de direito administrativo. São Paulo: Saraiva, 2006. p. 228.

${ }^{32}$ Neder e Lopes, Processo administrativo fiscal federal comentado, op. cit., p. 47.
} 
revista pelos órgãos do Poder Judiciário, o que faz com que esses últimos não façam coisa julgada material.

Paulo Cesar Conrado defende que a circunstância de a composição de conflito proporcionada pelos processos administrativos não se apresentar absoluta, não fazendo, portanto, coisa julgada, não lhe retira o caráter jurisdicional. Segundo Conrado, a atividade desenvolvida pela administração nos processos administrativos fiscais é típica manifestação jurisdicional, "não podendo funcionar como óbice para tal conclusão a inexistência da coisa julgada, uma vez não integrativa (ela própria, coisa julgada) daquele mesmo conceito" 33

Assim o fato de não fazer coisa julgada não retira do processo administrativo a qualidade de exercer função jurisdicional, tendo em vista que essa circunstância não é requisito essencial para a existência dessa atividade.

\section{Dos poderes do agente administrativo versus os poderes do julgador administrativo}

Outro argumento levantado em prol da incompetência dos julgadores administrativos em apreciar matéria constitucional é o fato de que a função dos agentes administrativos seria somente de executar a lei, sendo-lhes vedado, portanto, fazer juízos de compatibilidade dessa com o ordenamento constitucional.

$\mathrm{O}$ art. 37 da CF/88, com a redação dada pela Emenda Constitucional no 19/1998, dispõe que a administração pública direta e indireta de qualquer dos poderes da União, dos estados, do Distrito Federal e dos municípios obedecerá aos princípios de legalidade, impessoalidade, moralidade, publicidade e eficiência. Assim, o citado artigo elege a legalidade como um dos princípios básicos da administração pública.

O princípio da legalidade aplicado à administração pública, segundo Hely Lopes Meirelles, "significa que o administrador público está, em toda a sua atividade funcional, sujeito aos mandamentos da lei e às exigências do bem comum, e deles não se pode afastar ou desviar, sob pena de praticar ato inválido e expor-se a responsabilidade disciplinar, civil e criminal, conforme o caso". ${ }^{34}$

\footnotetext{
${ }^{33}$ Conrado, Processo tributário, op. cit., p. 108.

${ }^{34}$ MEIRELLES, Hely Lopes. Direito administrativo brasileiro. São Paulo: Malheiros, 2005. p. 87.
} 
Assim, segundo esse princípio, os agentes administrativos devem atuar conforme a lei, pois na administração pública "não há liberdade nem vontade pessoal" ${ }^{35}$ É já assente na doutrina que "enquanto na administração particular é lícito fazer tudo o que a lei não proíbe, na Administração Pública só é permitido fazer o que a lei autoriza". ${ }^{36}$ Celso Antônio Bandeira de Mello afirma que o princípio da legalidade "é a consagração da ideia de que a Administração Pública só pode ser exercida na conformidade da lei e que, de conseguinte, a atividade administrativa é atividade sublegal, infralegal, consistente na expedição de comandos complementares à lei" ${ }^{37}$

Do princípio da legalidade decorre o poder vinculado dos atos da administração pública, com relação ao qual "a norma condiciona sua expedição aos dados constantes de seu texto". ${ }^{38}$ Em outras palavras, por poder vinculado pode-se entender aquele em que o agente público fica inteiramente condicionado aos termos dispostos na lei. Segundo Celso Antônio Bandeira de Mello, atos vinculados "seriam aqueles em que, por existir prévia e objetiva tipificação legal do único possível comportamento da Administração em face de situação igualmente prevista em termos de objetividade absoluta, a Administração, ao expedi-los, não interfere com apreciação subjetiva nenhuma". ${ }^{39}$

Com base nesse princípio é que muitos argumentam que o julgador administrativo, na qualidade de agente público, deve fazer cumprir o disposto na lei, obrigatoriamente, posto que a lei é válida e vigente até que órgão competente a retire do ordenamento.

Sobre a possibilidade de descumprimento da lei ou ato normativo inconstitucional por parte do Poder Executivo, Alexandre de Moraes afirma que esse poder, assim como os demais, "está obrigado a pautar sua conduta pela estrita legalidade, observando, primeiramente, como primado do Estado de Direito Democrático, as normas constitucionais". ${ }^{40}$ Assim, caso o chefe do Poder Executivo entenda pela inconstitucionalidade de certa lei ou ato normativo, estaria ele desobrigado a cumpri-los. Este autor, no entanto, admite que este controle possa ser feito somente pelo chefe do Poder Executivo e não pelos órgãos subordinados.

\footnotetext{
${ }^{35}$ Ibid., p. 88.

36 Ibid.

${ }^{37}$ MELLO, Celso Antônio Bandeira de. Curso de direito administrativo. São Paulo: Malheiros, 2005. p. 89.

${ }^{38}$ Meirelles, Direito administrativo brasileiro, op. cit., p. 117.

${ }^{39}$ Ibid., p. 401.

${ }^{40}$ MORAES, Alexandre de. Direito constitucional. São Paulo: Atlas, 2007. p. 677.
} 
Ocorre que uma importante distinção deve aqui ser feita para melhor análise do tema: a função do agente administrativo e os atos por ele praticados não têm a mesma natureza e, portanto, não se submetem aos mesmos princípios e poderes que os atos praticados e as funções exercidas pelo julgador administrativo. Enquanto aquele exerce típica função administrativa, estando, por conseguinte, submetido ao princípio da legalidade e tendo seu poder vinculado à lei; este, o julgador administrativo, exerce função tipicamente jurisdicional, o que faz com que lhe sejam atribuídos outros tipos de poderes e funções.

$\mathrm{O}$ agente administrativo exerce, portanto, atos administrativos, considerados "toda manifestação unilateral de vontade da Administração Pública que, agindo nessa qualidade, tenha por fim imediato adquirir, resguardar, transferir, modificar, extinguir e declarar direito, ou impor obrigações aos administrados ou a si própria". ${ }^{41}$ Marçal Justen Filho define ato administrativo como "uma manifestação de vontade funcional apta a gerar efeitos jurídicos, produzida no exercício de função administrativa". ${ }^{42}$ Já Celso Antônio Bandeira de Mello o conceitua como “declaração do Estado (...) no exercício de prerrogativas públicas, manifestada mediante providências jurídicas complementares da lei a título de lhe dar cumprimento, e sujeitas a controle de legitimidade por órgão jurisdicional". ${ }^{43}$

Típico ato administrativo no direito tributário é o lançamento de ofício, segundo a dicção do art. 142 do CTN. ${ }^{44}$ Aliás, o próprio conceito de tributo insculpido no art. 3o do $\mathrm{CTN}^{45}$ fala que a sua cobrança será feita "mediante atividade administrativa plenamente vinculada". Nesse caso, o agente administrativo, representado pelo agente fiscal, deverá inexoravelmente respeitar o princípio da legalidade e seus poderes serão vinculados à letra da lei, esteja ela de acordo com o texto constitucional ou não.

\footnotetext{
${ }^{41}$ Meirelles, Direito administrativo brasileiro, op. cit., p. 149.

${ }^{42}$ Justen Filho, Curso de direito administrativo, op. cit., p. 191.

${ }^{43}$ Mello, de direito administrativo, op. cit., p. 358.

44 "Art. 142. Compete privativamente à autoridade administrativa constituir o crédito tributário pelo lançamento, assim entendido o procedimento administrativo tendente a verificar a ocorrência do fato gerador da obrigação correspondente, determinar a matéria tributável, calcular o montante do tributo devido, identificar o sujeito passivo e, sendo caso, propor a aplicação da penalidade cabível."

45 “Art. 3o Tributo é toda prestação pecuniária compulsória, em moeda ou cujo valor nela se possa exprimir, que não constitua sanção de ato ilícito, instituída em lei e cobrada mediante atividade administrativa plenamente vinculada."
} 
Já a função do julgador administrativo é ligada à atividade jurisdicional, na qual deverá interpretar e aplicar o direito diante de um caso concreto, com vistas a compor determinado conflito de interesses. Aqui, o agente público está vinculado ao ordenamento como um todo, devendo no exercício da jurisdição apreciar, inclusive, a compatibilidade da lei ou ato normativo a ser aplicado com a Constituição.

Assim, se a função jurisdicional pode e é efetivamente exercida pelo Poder Executivo, segundo os argumentos levantados no item anterior, necessário, portanto, se diferenciarem as competências atribuídas aos agentes administrativos que exerçam funções administrativas daqueles que cumprem funções jurisdicionais. Enquanto aqueles só podem agir nos estritos termos da lei, estes têm por função a aplicação do ordenamento jurídico como um todo ao caso concreto sob sua análise.

\section{Do controle difuso e concentrado de constitucionalidade das leis}

O ordenamento jurídico brasileiro prevê dois sistemas de controle jurisdicional de constitucionalidade das leis: o difuso e o concentrado. Por controle de constitucionalidade entende-se "a adequação (compatibilidade) de uma lei ou de um ato normativo com a Constituição, verificando seus requisitos formais e materiais" ${ }^{46} \mathrm{O}$ controle concentrado geralmente se dá de forma abstrata, ou seja, procura-se obter a declaração de inconstitucionalidade de uma norma em tese, desvinculada de um caso concreto. Já no controle difuso de normas, normalmente é também concreto, ou seja, a apreciação da inconstitucionalidade é incidental à análise do caso concreto, não sendo, portanto, objeto central da ação.

Segundo o art. 102 da Constituição Federal de $1988,{ }^{47}$ o controle concentrado das leis é de competência exclusiva do STF, podendo ser exercido através de ação direta de inconstitucionalidade ou ação declaratória de constitu-

\footnotetext{
${ }^{46}$ Moraes, Direito constitucional, op. cit., p. 676.

47 “Art. 102. Compete ao Supremo Tribunal Federal, precipuamente, a guarda da Constituição, cabendo-lhe: I - processar e julgar, originariamente: a) a ação direta de inconstitucionalidade de lei ou ato normativo federal ou estadual e a ação declaratória de constitucionalidade de lei ou ato normativo federal; (Redação dada pela Emenda Constitucional no 3 , de 1993) (...) III - julgar, mediante recurso extraordinário, as causas decididas em única ou última instância, quando a decisão recorrida: (...) b) declarar a inconstitucionalidade de tratado ou lei federal."
} 
cionalidade de lei ou ato normativo federal ou estadual (inciso I). O STF pode, ainda, mediante recurso extraordinário, julgar as causas decididas em única ou última instância, quando a decisão recorrida declarar a inconstitucionalidade de tratado ou lei federal (inciso III, b).

Cabe lembrar que o $\S 2^{\circ}$ do art. 102 da CF/88, com redação dada pela Emenda Constitucional no 45/2004, determina que as decisões definitivas de mérito, proferidas pelo STF, nas ações diretas de inconstitucionalidade e nas ações declaratórias de constitucionalidade, produzirão eficácia contra todos e efeito vinculante, relativamente aos demais órgãos do Poder Judiciário e à administração pública direta e indireta, nas esferas federal, estadual e municipal.

Se o controle concentrado é de competência exclusiva do STF, o controle difuso tem sido comumente caracterizado pela permissão, a todo e qualquer juiz ou tribunal, de realizar, diante de um caso concreto, a verificação da compatibilidade da norma com a Constituição Federal. ${ }^{48}$

O controle difuso de leis não é, portanto, exclusivo do Poder Judiciário, mas de todos os órgãos que exercem jurisdição. Há de se fazer a diferença, portanto, entre a atividade judicial e a jurisdicional. Assim, se os órgãos julgadores administrativos exercem atividade jurisdicional, podem eles igualmente apreciar a constitucionalidade das leis postas à sua analise. Sobre esse assunto, Marçal Justen Filho afirma que:

quando a Constituição consagrou a sistemática de controle jurisdicional de constitucionalidade das leis e atos normativos, não introduziu o monopólio da condição de defensor da Constituição. Em nenhum ponto, a Constituição previu que apenas o Poder Judiciário poderia conhecer o tema de constitucionalidades. ${ }^{49}$

$\mathrm{O}$ art. 97 da $\mathrm{CF} / 88^{50}$ dispõe, no entanto, que a declaração de inconstitucionalidade de lei ou ato normativo por parte dos tribunais deverá ser feita somente pelo voto da maioria absoluta de seus membros ou dos membros do respectivo órgão especial. Trata-se da cláusula de reserva de plenário que, se-

\footnotetext{
${ }^{48}$ Moraes, Direito constitucional, op. cit., p. 684.

${ }^{49}$ JUSTEN FILHO, Marçal. Ampla defesa e conhecimento de arguições de inconstitucionalidade e ilegalidade no processo administrativo. Revista Dialética de Direito Tributário, São Paulo, p. 72-73, 1997.

${ }^{50}$ Art. 97. Somente pelo voto da maioria absoluta de seus membros ou dos membros do respectivo órgão especial poderão os tribunais declarar a inconstitucionalidade de lei ou ato normativo do Poder Público.
} 
gundo Alexandre de Moraes, "não veda a possibilidade de o juiz monocrático declarar a inconstitucionalidade de lei ou ato normativo do Poder Público, mas, sim, determina uma regra especial aos tribunais para garantia de maior segurança jurídica".$^{51}$

Questão aqui seria saber se o controle difuso das normas estaria restrito aos julgadores do Poder Judiciário, ou igualmente aos julgadores administrativos. Ora, diante da análise dos dispositivos constitucionais, não encontramos nenhuma norma atribuindo competência exclusiva do controle difuso de constitucionalidade aos órgãos judiciais, ao contrário do que acontece com o controle concentrado, cuja competência, repita-se, é atribuída exclusivamente ao STF.

Desta forma, entende-se que a prerrogativa de se afastar a aplicação de determinada norma em virtude de uma incompatibilidade com a Constituição é de qualquer órgão jurisdicional (e não judicial), incluindo, portanto, os julgadores e tribunais administrativos, já que esses, conforme analisado acima, também exercem função jurisdicional.

Cabe ressaltar que, no controle difuso de constitucionalidade, "a lei que ofende a Constituição não desaparece, do corpo ou sistema de lei, podendo ainda ter aplicação noutro feito". ${ }^{52}$ Assim, esse tipo de controle não tem por consequência a invalidação e expulsão da norma inconstitucional do ordenamento jurídico, mas somente sua não aplicação ao caso concreto sub judice, por incompatibilidade com a Constituição.

Alberto Xavier ressalta que a análise constitucional feita pelo julgador administrativo é indireta, ou seja, se procede a uma "declaração de nulidade dos atos administrativos tributários por vício de inconstitucionalidade indireta", ${ }^{53}$ tendo em vista que ocorre a "mediação" da lei ordinária entre o ato administrativo e a Constituição. Segundo Xavier:

a apreciação da constitucionalidade das leis é mera questão prejudicial em relação ao objeto da decisão, que se refere à invalidade do ato administrativo de lançamento; questão prejudicial imprópria, pois se acumula com a questão objeto ao processo e cujo julgamento cabe ao

\footnotetext{
${ }^{51}$ Moraes, Direito constitucional, op. cit. p. 688.

${ }^{52}$ BONAVIDES, Paulo. Curso de direito constitucional. São Paulo: Malheiros, 2006. p. 303.

${ }^{53}$ XAVIER, Alberto. A questão da apreciação da inconstitucionalidade das leis pelos órgãos judicantes da administração fazendária. Revista Dialética de Direito Tributário, São Paulo, n. 103, p. 36, abr. 2004.
} 
mesmo órgão de aplicação do direito, não se devolvendo para outro processo ou outro órgão. ${ }^{54}$

Em conclusão, o afastamento de lei inconstitucional pelos julgadores administrativos não se trata de usurpação de competência alheia - do STF ou do Poder Judiciário - , mas, justamente ao contrário, é uma reafirmação da vinculação da administração pública ao primado da legalidade.

\section{O problema da interpretação e aplicação una e sistêmica do direito}

Um sistema de Constituição rígida resulta na superioridade da lei constitucional sobre a lei ordinária. Bonavides afirma que "a consequência dessa hierarquia é o reconhecimento da 'superlegalidade constitucional' que faz da Constituição a lei das leis, a lex legum, ou seja, a mais alta expressão jurídica de soberania". ${ }^{55}$ No mesmo sentido, Alexandre de Moraes afirma que "a ideia do controle de constitucionalidade está ligada à Supremacia da Constituição sobre todo o ordenamento jurídico e, também, à de rigidez e proteção dos direitos fundamentais". ${ }^{56}$ Por sua vez, José Afonso da Silva afirma que, sendo a Constituição a lei fundamental e suprema do Estado brasileiro, "todas as normas que integram a ordenação jurídica nacional só serão válidas se se conformarem com as normas da Constituição Federal" ${ }^{57}$

No campo do direito tributário, pelo fato de as disposições sobre o Sistema Tributário Nacional estarem amplamente constitucionalizadas, a Constituição passa a ser, por consequência, o pilar fundamental que orienta todo o direito tributário brasileiro. Roque Antônio Carrazza ressalta que "a Constituição é o critério último de existência e validade das demais normas do sistema do direito, pelo quê condiciona o agir (...) dos próprios Poderes Legislativo, Executivo e Judiciário".$^{58} \mathrm{O}$ mesmo autor afirma que todos os demais atos normativos infraconstitucionais só valerão e deverão ser observados "enquanto

\footnotetext{
54 Ibid.

${ }^{55}$ Bonavides, Curso de direito constitucional, op. cit., p. 296.

${ }^{56}$ Moraes, Direito constitucional, op. cit., p. 674.

${ }^{57}$ SILVA, José Afonso da. Curso de direito constitucional positivo. São Paulo: Malheiros, 2005. p. 46.

${ }^{58}$ CARRAZZA, Roque Antônio. Curso de direito constitucional tributário. São Paulo: Malheiros, 2011. p. 36.
} 
se harmonizam com as normas constitucionais, devendo ser interpretados e aplicados de modo a se ajustarem aos seus ditames". ${ }^{59}$

Assim, se a Constituição ocupa lugar de proeminência e serve de fundamento de validade a todas as demais normas tributárias, caberá ao intérprete e aplicador do direito verificar se as leis postas à sua análise estão em consonância com a Lei Maior. Na atividade jurisdicional - seja judicial ou administrativa - o julgador terá como tarefa primeira, portanto, analisar a constitucionalidade das leis a serem aplicadas ao caso concreto.

Sobre a aplicação do direito, Carlos Maximiliano ensina que "consiste no enquadrar um caso concreto em a norma jurídica adequada" ${ }^{60}$ Segundo esse jurista, esta adaptação de um preceito ao caso concreto pressupõe, primeiramente, "a crítica, a fim de apurar a autenticidade e, em seguida, a constitucionalidade da lei, regulamento ou ato jurídico", ${ }^{61}$ para depois se passar à interpretação, o suprimento de lacunas, as questões de ab-rogação e derrogação de preceitos. A aplicação, para Maximiliano, como termo geralmente empregado para exprimir a atividade prática do juiz, ou administrador, o ato final, somente pode ocorrer após o "exame da autenticidade, constitucionalidade e conteúdo da norma". ${ }^{62}$

Diante do exposto, o que ocorre se o julgador se deparar com lei em desacordo com o texto constitucional? Trata-se de um caso de antinomia entre as normas do sistema e, conforme visto, nesses casos as regras de maior escalão hierárquico - no caso, a Constituição - devem prevalecer. E essa regra vale para toda e qualquer atividade jurisdicional, seja ela praticada pelo Poder Judiciário ou pela administração pública.

Sobre o assunto, Alberto Xavier ensina que

Ao ser investida nesta função judicante, a Administração está vinculada à ordem jurídica global, ao sistema de fontes como um todo, ou se se preferir, ao princípio da juridicidade ou bloco de legalidade. (...)

Logo (...) se a Administração Pública deve obediência ao "bloco da legalidade", do qual a Constituição é o vértice supremo, essa mesma Ad-

\footnotetext{
${ }^{59}$ Ibid., p. 37.

${ }^{60}$ MAXIMILIANO, Carlos. Hermenêutica e aplicação do direito. Rio de Janeiro: Forense, 2002. p. 5.

${ }^{61}$ Ibid., p. 7.

${ }^{62} \mathrm{Ibid}$.
} 
ministração estaria desrespeitando tal bloco se aplicasse, por sua livre e espontânea iniciativa, uma lei inconstitucional. ${ }^{63}$

Conclui-se, portanto, que, se os órgãos julgadores administrativos exercem função jurisdicional, devem interpretar as leis de forma sistêmica, confrontando-as com o sistema tributário como um todo. Devem, portanto, impreterivelmente, analisar a constitucionalidade das mesmas. O ordenamento jurídico brasileiro é uno e sua interpretação e aplicação devem ser sistêmicas. Não é possível, repita-se, em um processo de interpretação e aplicação de leis a casos concretos, não levar em consideração as disposições da Constituição Federal, fundamento de validade de todas as demais normas. Não é possível excluir a Constituição do processo hermenêutico, como se quer fazer no âmbito do processo administrativo fiscal.

\section{Referências}

ALVIM, J.E. Carreira. Teoria geral do processo. Rio de Janeiro: Forense, 2007. CINTRA, Antonio Carlos de Araújo; GRINOVER, Ada Pellegrini; DINAMARCO, Cândido Rangel. Teoria geral do processo. São Paulo: Malheiros Editora, 2008.

BONAVIDES, Paulo. Curso de direito constitucional. São Paulo: Malheiros, 2006.

CARRAZZA, Roque Antônio. Curso de direito constitucional tributário. São Paulo: Malheiros, 2011.

CARVALHO, Paulo de Barros. Direito tributário: linguagem e método. São Paulo: Noeses, 2009.

CONRADO, Paulo Cesar. Processo tributário. São Paulo: Quartier Latin, 2004.

DINAMARCO, Cândido Rangel. Instituições de direito processual civil. São Paulo: Malheiros, 2005.

JUSTEN FILHO, Marçal. Curso de direito administrativo. São Paulo: Saraiva, 2006.

${ }^{63}$ Xavier, A questão da apreciação da inconstitucionalidade das leis, op. cit., p. 42. 
JUSTEN FILHO, Marçal. Ampla defesa e conhecimento de arguições de inconstitucionalidade e ilegalidade no processo administrativo. Revista Dialética de Direito Tributário, São Paulo, n. 25, p. 68-79, 1997.

MACHADO, Hugo de Brito. Algumas questões do processo administrativo tributário. In: MARTINS, Ives Gandra da Silva. Processo administrativo tributário. São Paulo: RT, 2002. p. 152-154.

MACHADO SEGUNDO, Hugo de Brito. Impossibilidade de declaração de inconstitucionalidade de lei pela autoridade administrativa de julgamento. Revista Dialética de Direito Tributário, São Paulo, n. 98, p. 91-99, 2003.

MAXIMILIANO, Carlos. Hermenêutica e aplicação do direito. Rio de Janeiro: Forense, 2002.

MELLO, Celso Antônio Bandeira de. Curso de direito administrativo. São Paulo: Malheiros, 2005.

MEIRELLES, Hely Lopes. Direito administrativo brasileiro. São Paulo: Malheiros, 2005.

MORAES, Alexandre de. Direito constitucional. São Paulo: Atlas, 2007.

NEDER, Marcos Vinícius; LOPES, Maria Teresa Martinez. Processo administrativo fiscal federal comentado. São Paulo: Dialética, 2004.

SILVA, José Afonso da. Curso de direito constitucional positivo. São Paulo: Malheiros, 2005.

XAVIER, Alberto. A questão da apreciação da inconstitucionalidade das leis pelos órgãos judicantes da administração fazendária. Revista Dialética de Direito Tributário, São Paulo, n. 103, p. 17-44, abr. 2004. 